\title{
A new Middle Pleistocene fauna from the Busidima-Telalak Region of the Afar, ETHIOPIA
}

\section{Zeresenay ALEMSEGED - Institute of Human Origins, Arizona State University, P.O.Box 874101, Tempe, AZ 85281-8159, USA}

\section{Denis GERAADS - CNRS UPR 2147 - 44 rue de l'Amiral Mouchez - F-75014 PARIS, France}

\section{Résumé}

Nous décrivons une nouvelle faune provenant de la région de Busidima-Telalak dans l'Afar, Ethiopie. Les fossiles proviennent surtout de sédiments fluviatiles de basse énergie. Durant notre première saison de terrain, trente et une espèces de mammifères ont été reconnues parmi les fossiles, abondants et bien conservés. Les plus communes sont les bovidés, les carnivores, les singes et les grands rongeurs. La faune indique un âge Pléistocène moyen ( 0,2 à $0,8 \mathrm{Ma})$. La reconstitution préliminaire du paléoenvironnement suggère que l'assemblage correspond à un milieu plutôt humide et fermé, contrastant donc avec la plupart des autres sites de cette période, qui attestent en général des environnements plus secs et ouverts.

\footnotetext{
Abstract

We report on a diverse fauna from the Busidima-Telalak region of the Afar in Ethiopia. The fossiliferous sediments are characterized by river bank deposits. During our first field season thirty one mammalian species were encountered. Fossils are nicely preserved and abundant. Bovids, carnivores, monkeys, and large rodents are the most common taxa. The fauna points to a Middle Pleistocene age (0.2 to $0.8 \mathrm{Ma})$. Our preliminary paleoenvironmental reconstruction indicates that our fossil assemblage is derived from a rather wet and closed environment. This condition is unique as sites of this time period were reported to be more open and dry.
}

\section{VERSION FRANÇAISE ABREGEE}

\section{Contexte}

La mission paléontologique de Busidima-Dikika a effectué une première campagne en Novembre 1999, surtout consacrée à la prospection de la région de Busidima-Telalak, sur la rive gauche de l'Awash, à l'Ouest de Hadar. Plusieurs localités y ont livré une riche faune (31 espèces) en excellent état de conservation. 
Cette région fait partie du bassin de l'Awash, où opèrent également les missions de Hadar, du Middle Awash et de Gona. La série sédimentaire, qui appartient au groupe de l'Awash (et peut-être à la Fm Wehaietu de Kalb \& al. $[13,15]$ comprend de bas en haut : un épais niveau de conglomérat ; un niveau silteux qui a livré la plupart des fossiles ; un second niveau fluviatile ; à Bironita, un tuf, dont la datation fournirait donc l'âge minimum des fossiles, sépare cette série d'un niveau supérieur de sables grossiers.

\section{Paléontologie}

Tous les fossiles proviennent de ramassages de surface, ni fouille ni tamisage n'ayant encore été entrepris. La liste faunique est la suivante :

\section{$\underline{\text { Rongeurs }}$}

Thryonomys cf swinderianus . Cette espèce de milieux humides remonte au Pliocène [23]. Aff Tachyoryctes sp.

Hystrix sp.

Arvicanthis sp. Un maxillaire ressemble plus à l'actuel A. niloticus qu'aux formes fossiles d'Olduvai [11], du lac Natron [5] ou de Tighenif [10].

\section{Primates}

Theropithecus oswaldi. Les dents d'Asbole sont semblables à celles de la sous-espèce la plus récente (moins de $1 \mathrm{Ma}$ ) et la plus évoluée, T. oswaldi leakeyi, connue à Olduvai beds II supérieur, III et IV, Olorgesailie, Tighenif, Hopefield et aux carrières Thomas [12, 7, 16]. Papio hamadryas ssp. Plusieurs restes crâniens ressemblent plus à ceux des diverses sous-espèces actuelles de $P$. hamadryas qu'aux formes fossiles est- et sud-africaines.

Cercopithecus cf aethiops. Ce taxon se distingue à peine de l'espèce actuelle mais il semble aussi voisin des cercopithèques de l'Omo [6,7] et de Taung [3], et un matériel plus complet serait bienvenu.

Procolobus sp. Ce singe, le plus abondant à Asbole, présente la morphologie dentaire et mandibulaire typique des Colobinés [19] et plus spécialement de Procolobus. Dans ce genre, il est plus proche de $P$. badius que de $P$. verus par la taille et l'absence de dépression infra-orbitaire. Il sera intéressant de la comparer plus en détail au $C$. cf. guereza signalé par Kalb et al. $[14,15]$ à Andalee. Ce site possède, comme Asbole, 3 espèces de Cercopithecidae, mais Papio y est absent.

\section{Carnivores}

\section{Cf Ichneumia sp.}

Hyaena cf hyaena.

Crocuta cf crocuta. 


\section{Panthera cf leo.}

Felis cf silvestris. Très commun, le chat sauvage l'était peut-être encore plus dans la biocénose. Canis sp.

Bien qu'aucune des espèces de Carnivores ne puisse formellement être distinguée des actuelles, il existe quelques indices de différence spécifique, et la plupart des formes actuelles sont d'origine ancienne.

\section{Proboscidiens}

Elephas recki cf recki. Une mandibule porte une molaire dont les proportions correspondent à celles de cette sous-espèce évoluée ([2], tab.81, Fig.90).

\section{Périssodactyles}

Equus sp. Cet Equidé, le seul retrouvé, pourrait être voisin du zèbre de Grévy.

Diceros sp. Le spécimen de rhinocéros le plus diagnostique appartient à ce genre, et il se pourrait qu'aucun des autres n'appartienne à Ceratotherium, espèce plus herbivore, ce qui suggérerait assurément un milieu assez fermé.

\section{$\underline{\text { Artiodactyles }}$}

Kolpochoerus majus. Le Suidé le plus commun à Asbole appartient à cette espèce, souvent mentionnée mais mal connue. Ses molaires sont restées primitives, mais la mandibule est remarquable par sa symphyse élargie.

Phacochoerus sp. Quelques dents de phacochère sont souvent associées aux outils acheuléens. Elles sont souvent considérées comme allogènes dans le Pléistocène inférieur et moyen, mais il se peut que ce genre soit en fait assez ancien.

Hippopotamus sp. L'hippopotame, remarquablement rare, est voisin de l'espèce actuelle. Les autres formes aquatiques, poissons et crocodiles, sont absentes. Il en est de même des girafes, qui fréquentent les savanes à acacias.

Tragelaphus scriptus. Quelques restes appartiennent à un petit guib, groupe présent dès le MioPliocène [8], mais toujours rare.

Cf Taurotragus sp. Un fragment de cheville appartient à un éland, antilope attestée à partir du Pléistocène moyen, mais dont l'histoire ancienne est mal connue.

Bos cf primigenius ? Le fossile le plus inattendu d'Asbole est un crâne incomplet de Bovini, au frontal long et aux insertions des cornes très postérieures, caractères qui ne s'accordent qu'avec Pelorovis oldowayensis et Bos, mais dans le premier de ces taxons les cornes sont très proches l'une de l'autre, et dirigées très postérieurement à la base. Le Bovini d'Asbole doit donc sans doute être rattaché à Bos, genre jusque là inconnu en Afrique orientale avant sa domestication. Syncerus sp. 
Oryx sp.

Kobus kob. Le cobe, espèce connue depuis le début du Pléistocène, est l'antilope la plus commune.

Redunca sp.

Damaliscus cf niro.

Aepyceros sp.

Gazella cf granti.

Gazella sp. 2. Une corne diffère un peu de l'actuelle G. thomsoni. Aucune, en revanche, ne peut être rattachée au springbok (Antidorcas), et il se peut qu'Asbole soit postérieur à son extinction en Afrique orientale.

\section{Archéologie}

De nombreux bifaces acheuléens ont été observés en surface, mais très peu ont été collectés, et leur étude reste à faire. Il est clair qu'il ne s'agit pas d'un Acheuléen primitif comme on l'a signalé à Konso [1, 18] ou à Garba IV à Melka Kunturé [17], mais l'influence du contexte sur la technologie interdit actuellement de tirer des conclusions chronologiques précises de celleci. Quoi qu'il en soit, cette industrie fixera un jalon supplémentaire dans l'évolution de l'Acheuléen, au cours de la période de transition entre Homo erectus et Homo sapiens.

\section{Conclusions}

Trois espèces de la faune d'Asbole, Elephas recki, Kolpochoerus majus et Theropithecus oswaldi, sont assurément éteintes, mais d'autres présentent aussi des caractères qu'on ne retrouve pas chez leurs équivalents actuels, et il se peut que le nombre de formes éteintes soit en fait supérieur. Aucun âge précis ne peut encore être proposé, mais une fourchette de 0.2 - 0.8 Ma peut être provisoirement retenue, avant la poursuite du travail de terrain.

L'assemblage faunique d'Asbole est remarquable par l'abondance et la diversité des Carnivores, sans doute liées au mode de formation de la taphocénose, et par la prédominance, chez les autres Mammifères, de formes de milieux humides et/ou fermés, contrastant avec ce qu'on rencontre habituellement dans le Pléistocène d'Afrique orientale, à la suite du changement climatique de la fin du Pliocène [4, 20, 21, 22]. De cette originalité découle l'intérêt de la faune d'Asbole, renforcé par la probabilité élevée d'y trouver des restes d'Hominidés qui illustreraient la période charnière de transition entre Homo erectus et Homo sapiens.

\section{ENGLISH VERSION}

\section{Background}


The Busidima-Dikika paleontological research project conducted its first fieldwork in November 1999. The study areas are exposed on both sides of the Awash River (figure 1). The western part (Busidima-Telalak) is bordered by the Middle Awash research area to the south and the Gona to the North, whereas the eastern part (Dikika), which is found south of Hadar is bordered by the Awash River to the north-west and the Mile-Addis-Ababa road to the East. This year's field season was mainly devoted to the exploration of the Busidima-Telalak area. Nothing was known about this area before our initial fieldwork, during which we covered only about $15 \%$ of the area for which we have the permit from the Ethiopian government. Nonetheless, at the few localities identified, we encountered an abundant and well preserved diverse mammalian fauna (31 species).

\section{Geology}

The area is part of the sedimentary basin where the Hadar, the Middle Awash and the Gona research projects are also located (figure 1). It was mapped as part of the RVRME (Rift Valley Research Mission in Ethiopia) geological work in the 1970s and the general stratigraphy of the area has been set $[13,15]$. The sediments belong to the Awash Group, which is more than one $\mathrm{km}$ thick and ranges from late Miocene to Holocene [13]. At Tikelibetelu, the succession is as follows, from base to top: 1) a very thick layer of conglomerate; 2) a silty layer which has yielded most of the fossils; 3) a second river bank deposit. At Bironita a tuff unit was encountered intercalated between the latter and a relatively thin $(50 \mathrm{~cm})$ layer of coarse sand with pebbles which caps this series. Dating of the tuff will hopefully provide the minimum age of most fossils. Sediments in Asbole could probably be correlated with some levels the Wahaietu Formation [13], but further geological studies need to be conducted.

\section{Paleontology}

The main goal of this field season was to look for as many fossiliferous localities as possible and not to collect all the fossils encountered. Neither excavation nor screening has been undertaken, and all fossils come from surface collections.

\section{$\underline{\text { Rodents }}$}

Thryonomyidae Thryonomys cf swinderianus The marsh cane-rat is represented by several more or less complete crania and mandibles, whose size match that of Th. swinderianus although the grooving pattern of the upper incisors is more like that illustrated for Th. gregorianus by Wesselman [23]. Both species have very old origins among Rodents ; the former could be dated 
back to Omo member B [23]. They both live in wet areas, Th. swinderianus being even semiaquatic.

Rhizomyidae Aff Tachyoryctes sp. This burrowing Rodent is common in Asbole, and shares similar molar morphology with the modern T. splendens and T. macrocephalus, but its $\mathrm{M}_{1}$ lacks an hypolophulid, and its affinities remain unclear.

\section{Hystricidae Hystrix sp.}

Muridae Arvicanthis sp. A maxilla with its 3 molars is more like the modern A. niloticus than like A. primaevus Jaeger, 1976 [11] from Olduvai by the relative positions of the tubercles of $\mathrm{M}^{1}$, and the more transverse (instead of $\mathrm{V}$-shaped) lophs of $\mathrm{M}^{2}$ and $\mathrm{M}^{3}$.

\section{$\underline{\text { Primates }}$}

Cercopithecinae Theropithecus oswaldi. The teeth morphology and size are comparable in general to that of specimens collected from Olorgesailie, Tighenif, Hopefield and Thomas Quarry, but the clefts and notches are slightly narrower than those from Hopefield. The corpus in Asbole mandibles is much shallower than that of most specimens from Hopefield, Thomas Quarry and Tighenif.

The length of the lower third molar in the T. oswaldi lineage is believed to increase constantly through time $[12,19,7,16]$. Based on this, two subspecies have been named, T. oswaldi oswaldi and T. oswaldi leakeyi that correspond roughly to before and after $1 \mathrm{Ma}$ respectively [16]. The length of the lower third molar of the Asbole theropith shows that our specimens belong to T. oswaldi leakeyi.

Papio hamadryas ssp. The Asbole male baboon has an elongated muzzle dorsum. There is a very deep maxillary fossa bounded by a ridge-like alveolar margin inferiorly and by a vertically oriented zygomatic bone posteriorly. The maxillary fossa is comparable in shape and size to that of $P$. hamadryas anubis, which is larger, but the alveolar margin in the Asbole baboon is more developed and expands laterally.

As in the living $P$. hamadryas, the male mandibular symphysis is very heavily built with a rough and pitted anterior surface. The mandibular fossa is deep and long. The thickness of the inferior edge of the corpus is thinner below $\mathrm{M}_{2}$ and becomes thicker anteriorly and posteriorly. The female mandible is much smaller, with shallower mandibular fossa and the thinnest part of the inferior margin of the corpus is below $\mathrm{M}_{1}$. The superior surface of the postorbital region is flat without any glabellar depression and postorbital sulcus. Most of the features in the Asbole baboon are variably observed in the extant Papio, but the Asbole baboon is closer in overall morphology and size to P. hamadryas hamadryas. 
The Asbole Papio differs from East African and South African fossil Papio species in that the maxillary fossa is deeper, the ridge bounding the fossa inferiorly is more pronounced, the superior surface of the female frontal is flatter and without any postorbital break or glabellar depression. Compared to the South African ones the Asbole male mandible differs, in addition, in having a longer and wider planum alveolare.

Cercopithecus cf aethiops. The $\mathrm{M}^{3}$ narrows posteriorly, has small talon but lacks a hypoconule and the distal fovea. Incisors are heteromorphic but not as much as in many extant cercopithecine species. The second incisors are characterized by a lateral wear facet that is often observed in cercopithecini. The mandibles have very shallow corpus, and no remarkable mandibular fossa. In both upper and lower teeth the second molars are larger than the first and the third. Among the many species of the genus Cercopithecus, they show more resemblance or less differences with C. aethiops even if the upper incisors in Asbole are much less heteromorphic and upper canines are much smaller. The lower third molar has a long and deep talonid fovea. Asbole specimens are much bigger than the ones from Kanam East [9] and molars are bigger than in L641-4 from Omo [7]. No clear morphological difference is observed between Asbole and P994-8a (from Omo) mandibles and the size of the $\mathrm{M}_{1}$ is comparable. The Asbole $\mathrm{M}_{3}$ and $\mathrm{M}_{2}$ are similar in shape and size to fossils form Taung [3].

Colobinae Procolobus sp. This is the most abundant primate taxon in the Asbole fossil assemblage. The fossils are readily attributable to the subfamily Colobinae because of the deep mandibular corpus, small incisors, molariform teeth and premolars with increased relief, lower molar lingual notches deeply incised and other characters [19]. The upper canines are small, the premolars are large relative to molars and $\mathrm{M}^{3} \mathrm{~s}$ have distal fovea. There is no infraorbital excavation, in contrast to $P$. verus, which is also smaller. The $\mathrm{M}_{3}$ has a well defined hypoconulid. The anterior teeth are small. The mandibular corpus is deep, the depth decreasing from below $\mathrm{M}_{3}$ posteriorly and anteriorly rendering the outline of inferior margin of the corpus convex and bulging. Modern Colobus do not show so clearly these set of features which are instead observed constantly in Procolobus badius. In addition female and male canine size in Asbole are comparable to those of the latter.

The coexistence of three cercopithecid species has been documented at the site of Andalee $[14,15]$. They may be close to those of Asbole, but Papio has not been reported from Andalee, and the colobine from Andalee was assigned to Colobus cf. guereza whereas the Asbole ones have more affinities with Procolobus badius. These discrepancies will be further explored in the near future. 


\section{Carnivores}

Viverridae Cf Ichneumia sp. A poorly preserved skull, with heavily worn dentition, is noticeable by its closed orbital ring, stout upper carnassial with strong protocone, and large molars, especially $\mathrm{M}^{2}$. The most similar extant species is I. albicauda, the white-tailed mongoose, but the $\mathrm{P}^{4}$ is slightly different, with a narrow metastyle and concave postero-internal border, giving it a different outline. The only known fossil species of this genus, I. nims Geraads, 1997, is represented only by lower teeth from the late Pliocene of Morocco.

Hyaenidae Hyaena cf hyaena A partial skull with most of the left dentition is slightly different from most modern specimens in that the axis of $\mathrm{P}^{2}$ is not angled on the axis of the tooth-row, and the auditory bulla is less inflated, but these features are variable in the Recent form. H. hyaena is known from member $\mathrm{C}$ onwards at Omo.

Crocuta cf crocuta A fragment of mandible with a complete carnassial is typical of this genus by its short simple talonid. The size and narrowness of the teeth, together with the lack of metaconid make it close to the living $C$. crocuta, which probably dates from the earliest Pleistocene.

Felidae Panthera cf leo A fragment of upper carnassial is similar to that of the Recent lion. Felis cf silvestris The wild-cat is the most common carnivore in spite of its small size, which could have led to its under-representation in the collected sample. It might have been still more common in the biocenosis.

Canidae Canis sp. A canid, the size of a jackal, is also rather common. The best preserved upper carnassial has a larger protocone than in modern Canis, but it is not so large in other specimens, and this feature is among the most variable ones in Canids.

None of the carnivores could be definitely distinguished from their modern analogues in this preliminary study, but most of the living species are certainly of rather ancient origin, and there are several hints of specific distinctiveness in the Asbole Carnivores, which remain to be further substantiated.

\section{Proboscideans}

Elephas recki cf recki A fragment of mandible bears a molar which is probably an $\mathrm{M}_{2}$, incomplete posteriorly. The plates are little worn; in earliest wear, they consist of numerous isolated islands which later fuse into anteriorly concave plates, without any tendency towards a loxodont shape and with only a minor median expansion. The height dimension of the most posterior plate (the $11^{\text {th }}$ ) is twice that of the breadth. An unknown number of plates (probably at least 2) are missing posteriorly. The proportions and morphology of this tooth are similar to those of E. recki recki from Koobi Fora ([2], tab.81, Fig.90) and we refer it tentatively to this subspecies, the last one of the E. recki lineage. 


\section{Perissodactyla}

Equidae Equus sp. A few teeth belong to this genus, while there is no evidence of Hipparion, a genus still occasionally present in the Early Pleistocene. The large size, and "stenonian" pattern of the double-knot of lower teeth point to a zebra close to E. grevyi.

Rhinocerotidae Diceros sp. The best Rhino specimen, a maxillary fragment, is definitely of Diceros, and most other remains are also of the right size and morphology to belong to this genus. No specimen can unambiguously be referred to Ceratotherium, which is by far the most common Rhino in the Plio-Pleistocene of Africa. Although neither is exclusive in its feeding behaviour, Diceros is certainly more a browser than Ceratotherium, and the rarity of the latter points towards a rather closed habitat.

Artiodactyla

Suidae Kolpochoerus majus The most common Suid from Asbole belongs to Kolpochoerus majus, a species which has been reported from several localities, but remains poorly known. The $\mathrm{M}_{3 \mathrm{~s}}$ can be distinguished from those of $K$. afarensis by the presence of 3 pairs of pillars, instead of two, by the presence of two median pillars between the second and the third pairs of pillars, instead of one with an incipient division, and by its greater hypsodonty. Amongst Omo $K$. limnetes, $\mathrm{M}_{3}$ s from around Member $\mathrm{C}$ are closer to the ones from Asbole, but the talonid is formed by a single pillar which joins the third pair of pillars. The $\mathrm{P}_{4}$ has a strong median pillar underlined by two lingual grooves, and a low narrow talonid, while that of $K$. afarensis has a weak main tubercle, and a high broad talonid. $\mathrm{P}_{3}$ differs by the same features, but less clearly.

In the upper third molar the cusps are more complex than in $K$. afarensis. There are more accessory pillars, as in $K$. phacochoeroides, but less pronounced than in the later. Lateral pillars are closer to each other than in $K$. limnetes, and this tooth is not narrowed posteriorly.

In superior view the lateral contour of the mandible is regularly convex with a slight concavity at the level of the diastema. In K. afarensis and K. limnetes there is a strong bulge at the level of molars and premolars and then a concave region between the fourth premolar and the canine. The symphysis is clearly wider than in these species, with a convex rather than concave ventral side.

Phacochoerus sp. Several warthog teeth were found, often associated with Acheulean artefacts. Warthog teeth are often considered as intrusive in Lower and Middle Pleistocene sites, but there remains a possibility that this genus is of earlier appearance than usually thought.

Hippopotamidae Hippopotamus sp. A fragment of maxilla with much worn molars could be of H. amphibius, being seemingly less hypsodont than H. gorgops, but more material is needed to 
confirm this. However, remains of Hippos are remarkably rare, and no fish or crocodile has been found.

No Giraffid has been found. The environment might have been too wet and/or woody for them.

Bovidae Tragelaphus scriptus Two horn-cores (juvenile and adult) and two mandible fragments are of a small bushbuck, a group which is rare in the African fossil record, but of very ancient origin, being already present in the Mio-Pliocene of Uganda [8].

Cf Taurotragus sp. A horn-core fragment belongs to an eland and we refer a few mandibular fragments of a large Tragelaphine to the same genus, of which there is no definite record before the Middle Pleistocene, but the earlier history of which is little known.

Bos cf primigenius? One of the most surprising findings was that of the posterior part of a Bovine skull that should be referred to the mainly Palearctic genus Bos. It includes both orbits, the whole forehead, top of the occipital and bases of horn-cores, but the latter are missing, as well as the muzzle, teeth, and cranial base. It is of very large size, and its most noticeable features are its long flat forehead, and the extremely posterior position of the horn-core bases, with a strong ridge between them, overhanging the hollowed occipital. The orientation of the horns cannot be precisely determined, but they were certainly extremely diverging (perhaps by an angle of about $150^{\circ}$ ), directed laterally and slightly backwards at the base (but because of their large size, head balance implies that they must have been curved forwards in their upper part). The only other Bovine with a similar horn-core position and insertion is the lower Pleistocene Pelorovis oldowayensis, whose horn-cores are much closer together at the back of the skull, and not connected by a thick bony ridge overhanging the occipital. The Middle Pleistocene P.antiquus, instead, has horn-cores insertions more like those of Syncerus, and an intermediate species might look like the Asbole Bovine, but we believe that this ancestor-descendant relationship is unlikely. The Asbole Bovine skull should therefore probably be identified as Bos, a genus that had not previously been reported from East Africa before its domestication.

Syncerus sp. A well preserved lower jaw is unlike Bos by its molarized $\mathrm{P}_{4}$ and pinched lateral lobes of its molars, and much more like those of the African buffaloes.

Oryx sp. A single horn-core fragment can be identified by its straight course, and almost rounded cross-section.

Kobus kob By far the most common Bovid of the Asbole fauna is a kob similar to the living species. The horn-cores diverge basally, but the divergence decreases upwards. In lateral view, the lower part is strongly curved backwards, but the tips are curved forwards, although not hookshaped. Cross sectional shape is somewhat variable, compression being usually moderate, with 
sometimes a flattened lateral surface and a hint of a postero-lateral keel. The part of the horn which is curved forwards is often flattened anteriorly. There are about 8-10 transverse ridges.

No feature distinguishes our specimens from $K . k o b$, a species which is rather widespread, with local variants, and is known since bed II times at Olduvai, and KBS member at Koobi Fora. Redunca sp. Two mandibles are smaller than those of $K$. kob, and their $\mathrm{P}_{4} \mathrm{~S}$ differ in that the talonid is longer, the hypoconid less salient buccally, and the metaconid more transversal. These features match better those of Redunca, the reedbuck.

Damaliscus cf niro An incomplete right horn-core with part of the braincase is of doubtful identification. The horn-core is curved backwards, not very compressed transversely, with a large basal sinus and weak transverse ridges. There is a long shallow post-cornual fossa, as in D. niro. However, the horn-core is slightly less compressed than in the latter species, and the brain-case looks longer, and with a straighter upper profile, than in Damaliscus but, as far as we know, no complete brain-case of $D$. niro has been described. $D$. niro is known from bed II onwards at Olduvai, and could have existed till the late Pleistocene of South Africa. It is therefore not useful in dating the Asbole fauna.

Aepyceros sp. A fragment of horn-core matches that of the impala, known since the Pliocene. Gazella cf granti A horn-core base is strongly compressed transversely, curved backwards but neither curved outwards nor twisted. It must belong to a large Gazella, but is slightly smaller and perhaps less extremely flattened than in G. granti. An almost complete mandible, lacking only $\mathrm{P}_{2}$, is definitely of Gazella because of its long premolars, primitive $\mathrm{P}_{4}$ without lingual wall, and incipient goat folds on molars. It is somewhat larger than Recent G. granti, and thus perhaps not co-specific with the above-mentioned horn-core.

Gazella sp. 2 Another horn-core is much like the modern G. thomsoni, being almost straight, smaller than the former one, with a more flattened lateral surface, but it is more inclined backwards than in G. thomsoni. Two lower molars could be of the same species, or of Antidorcas, the springbok, but no horn-core of this genus, so common in the African Plio-Pleistocene, has been found, and the Asbole fauna might post-date its extinction in East Africa.

Gazelles were evidently not rare components of the Asbole fauna, but more material is needed before the number of species present, and their precise identity, could be ascertained.

\section{Archaeology}

Numerous Acheulean artefacts occur as surface finds in the Busidima-Telalak area, but only a few were collected. We have not yet established the stratigraphic relationship between the 
artefacts and the fossils of the area, but it seems that the artefacts are derived from the upper river bank sediments.

Changes through time from the oldest to the youngest representatives of the Acheulean culture are still imperfectly documented. We are clearly not dealing here with an early technology such as the one found in Konso [1, 18] or Garba IV at Melka Kunture [17], but it is hard to provide a chronological estimate, since technology much depends on the geographic setting. We hope that stone tools recovered from Asbole will shed light on the evolution of the Acheulean industry, thus contributing to our understanding of the evolution of this culture and early Homo erectus and/or archaic Homo sapiens behaviour during a long and poorly documented time interval.

\section{Conclusions}

\section{Biochronology}

Three species of the Asbole fauna, Elephas recki, Kolpochoerus majus and T. oswaldi are definitely extinct. They have been reported by Kalb \& al. [14] from the Andalee member of the Wehaietu Fm which dates, according to these authors, from the Middle / Upper Pleistocene. In addition, many other species from Asbole display features not found in living taxa, and the exact number of extinct forms may be higher. No precise biochronological dating can be provided at the present, but the range $0.2-0.8$ seems plausible. However, it is possible that two stratigraphic horizons are represented by our fossil assemblage. Thus additional systematic collection of nonhominid fossils will be undertaken in order to understand the faunal composition of the new area thoroughly.

\section{Environment}

Perhaps the most striking feature of the Asbole assemblage is the great number and diversity of carnivores, probably exceeding those found in a living community. Some of them are excellently preserved: the Ichneumia skull is articulated with its mandible, and Canid remains include part of a at least one partial skeleton, implying that bodies were not transported over long distances.

Also noticeably abundant are the monkeys, represented by numerous jaws, and at least 4 species. This diversity, and the occurrence of a species similar to present-day forest-dwelling colobines, suggests the proximity of forest environment. The predominance of Reduncines points to a wet environment, while Tragelaphines suggest bushes and thickets. On the whole, the ecological implications of the Bovid assemblage recalls more some Pliocene sites than Pleistocene ones. Some of the rodents indicate wet and sub-aquatic environment. The absence or 
rarity of taxa that indicate open savannah, such as Alcelaphines, Giraffa, Ceratotherium, Equidae, and taxa that indicate open water, such as Hippos, crocodiles and fishes is to be noted. At least part of the sample may be from a gallery forest. It is clear, anyway, that the Asbole fauna documents a relatively wet and forested environment.

It is generally accepted that environmental conditions became more open and xeric through time in the Plio-Pleistocene, with cooler and drier conditions in the late Lower Pleistocene[4, 20, 21, 22]. The fauna collected from Asbole, instead, indicates humid and closed conditions. One of our goals is therefore, to provide paleoenvironmental and paleoecological reconstructions, and test some environmental hypotheses of this critical time-period, which corresponds to the transition from Homo erectus to Homo sapiens. They may also provide insight into the exodus of $H$. sapiens into the rest of the world.

Finally the probability of finding hominids in the new area is high. Some of our taxa that are important from biostratigraphic point of view have been reported from the hominid site of Bodo in the Middle Awash, which is dated to circa 0.6 Ma (Kolpochoerus cf. majus and Theropithecus oswaldi). One of our main aims will be to survey systematically for hominid remains, both in the localities already established and in new areas. Hopefully, they will provide needed information on the morphology of late $H$. erectus or early $H$. sapiens from Africa, as there are very few fossils from this time period.

\section{Acknowledgements}

We would like to thank the Center for Research and Conservation of Cultural Heritage for giving us permission to conduct field work. We are grateful to the CNRS (Programme "Paléoenvironnement, Evolution des Hominidés"), Centre Français d'Etudes Ethiopiennes and Institute of Human Origins for their financial and logistical support. Our thanks go to the American Museum of Natural History where Z.A. conducted comparative studies of monkeys, and from where he obtained a partial financial aid. We are highly indebted to E.Delson who allowed Z.A. to work on his fossils casts. Moreover, Z.A. would like thank E. Delson, S. Frost, and E. Sarmiento for their help at the American Museum of Natural History and for useful discussions. Thanks to Bob Randal, Alemu Admassu and Asamrew Dessie. This work would not have been possible without the help of the Afars of the Busidima region, thanks to them.

\section{References:}

[1] Asfaw B., Beyene Y., Suwa G., Walter R.C., White T.D., WoldeGabriel G., Yemane, T. The earliest Acheulian from Konso-Gardula. Nature, 360 (1992) 732-735. 
[2] Beden M. Les Eléphants (Loxodonta et Elephas) d'Afrique Orientale; systématique, phylogénie, intérêt biochronologique. Thèse Univ.Poitiers, 567 p. (1979) (inédit).

[3] Broadfield D.C., Delson E., Atsalis, S. Cercopithecid fossils from the later Pleistocene of Taung, South Africa. Am. J. Phys. Anthropol. 18 (1994) Suppl. 59-60.

[4] Coppens Y. Evolution des Hominidés et de leurs environnements au cours du Plio-Pléistocène dans la basse vallée de l'Omo en Ethiopie. C.R. Acad. Sc. Paris, D, 281 (1975) 1693-1696.

[5] Denys C. Chap. 6.1 Fossil Rodents (other than Pedetidae) from Laetoli. P. 118-170, In: M.D.LEAKEY \& J.M.HARRIS (Eds), Laetoli, a Pliocene site in Northern Tanzania. Oxford University Press, 1987.

[6] Eck G.G., Howell F.C. New fossil Cercopithecus material from the lower Omo basin, Ethiopia. Folia. Primatol. 18 (1972) 325-355.

[7] Eck, G.G. Plio-Pleistocene specimens of Cercopithecus from the Shungura Formation, southwestern Ethiopia.In: (G.G. Eck, N.G. Jablonski and M. Leakey eds.) Les faunes pliopléistocènes de la basse vallée de l'Omo (Ethiopie), Vol.3 Cercopithecidae de la Formation de Shungura, pp. 142-145. Paris CNRS, 1987.

[8] Geraads D., Thomas H. Bovidés du Plio-Pléistocène d'Ouganda. pp.383-407 in: Pickford M. and B. Senut (eds.), Geology and Palaeontology of the Albertine Rift valley, Uganda-Zaire. II. CIFEG, Publication occasionnelle 29 (1994).

[9] Harrison T., Harris E.E. Plio-Pleistocene Cercopithecids from Kanam East, western Kenya. $J$. Hum. Evol. 30 (1996): 539-561.

[10] Jaeger J.-J. Evolution des Rongeurs, du Miocène à l'actuel, en Afrique nord-occidentale. Thèse Univ. Montpellier, 1975, CNRS nºO 11538.

[11] Jaeger J.-J. Les Rongeurs (Mammalia, Rodentia) du Pléistocène inférieur d'Olduvai bed I (Tanzanie). Ière partie: les Muridés. P.57-120 in: R.J.G.Savage \& S.C.Coryndon (eds): Fossil Vertebrates of Africa, 4. Academic Press, London, 1976.

[12] Jolly C.J. The classification and natural history of Theropithecus (Simopithecus) (Andrews, 1916) baboons of the African Plio-Pleistocene. Bulletin of the British Museum (Natural History), 22 (1972) 1-123.

[13] Kalb J.E., Oswald E.B., Tebedge S., Mebrate A., Tola E., Peak, D. Geology and stratigraphy of Neogene deposits, Middle Awash Valley, Ethiopia. Nature, 298 (1982a) 17-25.

[14] Kalb J.E., Jolly C.J., Mebrate A., Tebedge S., Smart C., Smart E.B., Oswald E.B., Cramer D., Whitehead P., Wood C.B., Conroy G.C., Adefris T., Sperling L., Kena B. Fossil mammals and artefacts from the Middle Awash Valley, Ethiopia. Nature, 298 (1982b) 25-29. 
[15] Kalb J.E., Jaegar M., Jolly C.J., Kena, B. Preliminary Geology, Paleontology and Paleoecology of a Sangoan Site at Andalee, Middle Awash Valley, Ethiopia. J. Archaeo. Sci. 9 (1982c) 349-363.

[16] Leakey M.G. Evolution of Theropithecus in the Turkana Basin. In: (N.G. Jablonski, ed.) Theropithecus. The Rise and the Fall of a Primate Genus. pp. 227-243. Cambridge: Cambridge University Press, 1993.

[17] Piperno M., Bulgarelli-Piperno, G. First approach to the ecological and cultural significance of the early palaeolithic occupation site of Garba IV at Melka Kunturé (Ethiopia). Quaternaria, 18 (1975) 347-382.

[18] Suwa G. et al. (1997) The first skull of Australopithecus boisei. Nature, 389 :489-492.

[19] Szalay F.S., Delson E. Evolutionary History of the Primates. London: Academic Press, 1979. [20] Vrba E.S. Ecological and Adaptive changes Associated With Early Hominid Evolution. In : Delson, E. (ed.), Ancestors: The Hard Evidence, pp. 63-71.Alan R. Liss, New York, 1985. [21] Vrba E.S. Late Pliocene climatic events and hominid evolution. In : F. Grine (ed) Evolutionary history of the robust australopithecine. De Gruyter, New York, pp. 405-426, 1988. [22] Vrba E.S. The Fossil Record of African Antelopes (Mammalia, Bovidae) in relation to Human Evolution and Paleoclimate. In : Vrba E.S., Denton G.H., Partridge T.C. \& Burkle L.H. (eds.), Paleoclimate and evolution, with emphasis on human origins, pp. 385-424. Yale University Press, New Haven, 1995.

[23] Wesselman H.B. The Omo micromammals. Contributions to Vertebrate Evolution, 7 (1984) $1-219$.

\section{Caption to figure / Légende de la figure}

Sketch map of the Busidima - Telalak area. Dots indicate the fossil localities. Carte schématique de la région de Busidima - Telalak. Les points indiquent les localités fossilifères.

\section{Denis GERAADS}

CNRS UPR 2147

44 rue de l'Amiral Mouchez

F-75014 PARIS, FRANCE

dgeraads@ivry.cnrs.fr

tel $33(0) 143135621$

fax $33(0) 143135630$ 